Jurnal Linguistik Terapan Pascasarjana

Available online

http://jurnal.unimed.ac.id/2019/index.php/JLT-Unimed

\title{
IMPOLITENESS STRATEGIES USED BY GOVERNOR CANDIDATES OF DKI JAKARTA IN GOVERNOR ELECTION DEBATE 2017
}

\author{
Yohana Debora Siburian
}

Sri Minda Murni

Busmin Gurning

\author{
English Applied Linguistics Program
}

Postgraduate Program-Universitas Negeri Medan

Diterima Desember 2018; Disetujui Februari 2019; Dipublikasikan April 2019

\begin{abstract}
This study aimed at exploring the impoliteness strategies in governor election debate 2017. The objectives of the study were to describe, to explain how types of impoliteness strategies used and to expose the reasons. This research applied descriptive qualitative method. The data were the utterances of the governor candidates in two different debate sessions which were analyzed by using Culpeper Impoliteness Theory. The findings revealed that there were three out of five impoliteness strategies found in both debates, namely bald on record impoliteness, positive impoliteness and negative impoliteness. The governor candidates used the bald on record in three realizations, positive impoliteness in seven realizations and negative impoliteness in three realizations. There are some reasons of using the impoliteness strategies, namely to vent negative feelings, to mock others, to show disagreement, to show power, and to clarify something. However, the main reason to use the impoliteness strategies was to show power. Moreover, it is also revealed that both two different types of impoliteness strategies and two different realizations were used at the same moment.
\end{abstract}

Keywords: election debate, governor candidates, impoliteness strategies

How to Cite: Siburian, Yohana Debora (2019).

Impoliteness Strategies Used by Governor Candidates of DKI Jakarta in Governor Election Debate 2017. Jurnal Linguistik Terapan Pascasarjana Unimed, 16 (1): 365-378

*Corresponding author:

ISSN 0216-5139

E-mail: Yohanadeborasib51@gmail.com 


\section{INTRODUCTION}

A good communication is one that comes from a speaker who can convey good messages to the audiences so that the audiences can understand or give a good feedback in order to create communication. Therefore, before performing a conversation, the speaker needs to consider several things, example of how social relations with the audiences, where the event occurs, and to what the conversation is done. In fact, the speaker task is to keep the conversation going well, is not jammed, not in vain, and the social relationship between the audiences of the conversation is not disturbed. Attitude of the speaker also becomes a factor in creating a good conversation which leads to the application of impoliteness as an important strategy that must be done by the participants in the communication and aims to maintain harmonious atmosphere Culpeper[1].

Beard [2] states study the language of politics is important because it helps the language users to understand how language is used by those who wish to gain power, those who wish to exercise power and those who wish to keep power. Moreover, language has a powerful tool in the hands of political leaders.In implementation of successful democratic rule in any country language of politics is essential. Aeyomoni and Akinkuolere[3]observe that language is the conveyer belt of power, it moves people to vote, debate.

Language is essential to politicians. Beard [2]elaborates the politician is a practitioner of the art of politics, essential to the working of human society. The language of politics provides the opportunity for politicians to explore the resources available through language to manipulate words to persuade them. Therefore, language could be regarded as the vehicle of politics. The governor candidates also politicians, because politics is the practice to influence of other people to achieved and exercise positions of governor. One activities perform by the politicians are done through the language like speech or debate. In recent years, political debates between governor candidates become one of interesting case to discuss they give lip 
service as it is a reality that must be ahead of the election, because basically they want to win at the time of the next election, so that they will give their best to get to the heart of society so that people would choose him to be a leader.

Based on researcher's observation, the governor candidates of DKI Jakarta also utilized the impolite strategies to make other candidates feel uncomfortable. Impolite utterances of one candidate AniesRasyidBaswedan (ARB) as can be seen in the following situation:

\section{$A R B$ : "Firaun pencuri pun bisa dengan jujur menceritakannya."}

From the situation above, the utterance of "Firaun pencuri pun bisa dengan jujur menceritakannya." is the positive impoliteness which realization call other names .

Culpeper [1] stated the positive impoliteness is the use of strategies to damage the addressee's positive wants, including ignore, make other feel uncomfortable, snub the other, use inappropriate identity makers and call other names. He tried to make the other candidate (BTP) feel uncomfortable because he asked about his previous promise for DKI Jakarta as the governor in his period. Related to the explanations above, the researcher is interested to analyze impoliteness utterance of governor candidates in governor election DKI Jakarta 2017 because when the candidates are debating, there are some rules that should be obeyed to make the hearers feel comfortable related to the language used by the candidates. Each candidates should be wise to choose the language especially about how to deliver opinion and how to respond the argument if they disagree with statements uttered by the other candidate. The candidates' language must have significant effects on the opponent. This research intends to describe the types of impoliteness strategies, to explain how those types of impoliteness strategies linguistically realized and to expose the reason why the impoliteness strategies linguistically used by the governor candidates in DKI Jakarta election debate 2017. 


\section{REVIEW OF LITERATURE}

\section{A. The Concept of Impoliteness}

The concept of impoliteness is the opposite of politeness. When one act politely, he is trying to get along with other people and try to ensure that the communication goes on smoothly. If for some reason one wants to be impolite towards other people he is deliberately attacking others with his speech or want to create a social interruption. People often express their feelings with impolite language that can cause conflict. They often cannot control their behavior or language when they communicate to others. They do not think about politeness strategy but they prefer to perform impoliteness strategy to express their feelings.

Culpeper [1] defines impoliteness as a situation where a speaker communicates faceattack intentionally, or when the hearer perceives and/or constructbehaviour as intentionally face-attacking, or a combination of both. He further states that impoliteness comes about when: (1) the speaker communicates face attack intentionally, or (2) the hearer perceives and/ or constructs behavior as intentionally face tacking, or a combination of (1) and (2). In addition, there are some terms that refer to the same meaning with impoliteness; it is the term of rudeness. The term of impoliteness and rudeness have the same meaning in negative attitude. Lakoff[4] then asserts that rude behavior does not use the strategies of politeness when those strategies are hoped to do, in other ways that the utterance can be meant as deliberately and negatively argumentative.

\section{B. Impoliteness Strategies}

Culpeper makes a theory which explains an intended act to attack someone's face. He calls his theory as the theory of impoliteness strategy. Compared to Lachenict's strategies, Culpeper's strategies are more comprehensive as they consist of five strategies; meanwhile, Lachenict's strategies consist of four strategies. The impoliteness strategies which are made by Culpeper are: bald on record impoliteness, positive impoliteness, negative impoliteness, 
sacrasm or mock impoliteness, and witholdimpoliteness. These impoliteness strategies are a means of tracking the hearers' face.

\section{Bald on Record Impoliteness}

Bald on records impoliteness is performed in a direct, clear, unambiguous and concise way and the speaker's intention is to attack the hearer's face. A revised version of this strategy in Culpeper [1]takes into consideration that in this case there is a lot of face at stake and the speaker's intention is to attack the hearer's face or where the speaker does not have the power to (safely) utter an impolite utterance. He has categorized the realization of bald on record impoliteness into 1) direct, 2) clear, 3) unambiguous, and 4) concise way.

\section{Positive Impoliteness}

Positive impoliteness is a strategy directed to attack the hearer's positive face. Brown characterized positive face be desire to be liked, admired, ratified, and related to positively, nothing that one would threaten positive face by ignoring someone possible positive impoliteness realizations: 1)ignore, snub the other, 2)exclude the other from an activity, 3)dissasociate from the other, 4)be disinterested, unconcerned, unsympathetic, 5)use inappropriate identity markers, 6)use obsecure or secretive language, 7)seek disagreement, 8)make other feel uncomfortable, 9)use taboo words, and 10)call other names.

\section{Negative Impoliteness}

Negative impoliteness is a strategy used to attack the hearer's negative face. Negative face is the desire not to be imposed upon, nothing that negative face could be impinged upon by imposing on someone. The realizations are : 1)frighten, 2)condescend, scorn or ridicule, 3)invade the other's space, 4)explicitly associate the other with the negative aspect, 5)put the other indebtedness on record. Culpeper et al [1] add another strategy into this category, which is hindering or blocking the other physically or linguistically.

\section{Sarcasm or Mock Impoliteness}


Culpeper [1]stated that Sarcasm or mock impoliteness is performed with the use of politeness strategies that are obviously insirece, and thus remain surface realizations. In this case, someone uses this strategy as following threatened face done by applying politeness strategies that actually just pretending.In addition, Culpeper's theory of sarcasm or mock impoliteness is close to Leech's [5]conception if irony "If you must cause offence, at least do so in a way which does not overtly conflict with the PP, but allows the hearer to arrive at the offensive point of your remark indirectly, by way of an implicature".

\section{Withold Impoliteness}

Culpeper [1] explains withhold impoliteness occurs when someone prefers to keep silent when a polite act is hoped to be performed by the others. The realization of withhold impoliteness are being silent and failing to thank.

\section{Reasons of Using Impoliteness Strategies}

There are some functions of rudeness which relates to the impoliteness according to Babee in Culpeper. They are: (1) to show disagreement, (2) to vent negative feelings, (3) to mock others, (4) to clarify something and (5) to show power.

\section{METHODOLOGY}

The study applies descriptive qualitative research design by describing the phenomena of language in society. In this case, the answers of the research problem in this study are answered by giving explanation or describing the impoliteness strategies of the utterances in governor candidates' interaction in detail. According to Bogdan\&Biklen[6]stated that the design used in the research refers to the researcher's plan of how to proceed. The source of data in this study is the governor candidates of governor election debate of DKI Jakarta 2017.

The data was the utterances in debates which were taken from videos and then transcribed into written text. There are twelve sections of debate from 13 January 2017 until 10 February 2017, but in this research there were only five sections taken namely 13 January 
2017 (Pembangunan Demokrasi dan Pemerintahan yang Efektif), 27 January 2017

(Birokrasi, Pelayanan Publik, dan Penataan Kawasan Perkotaan) to be analyzed in this study.The data are then analyzed by applying Miles \& Huberman's (2014) analysis model which considered of three steps namely 1) data condensation, 2)data display, and 3) conclusion drawing and verification.

\section{FINDINGS AND DISCUSSIONS}

After analyzing the data, the findings of this can be seen in the figure below:

Figure 4.1 Types of Impoliteness Strategies

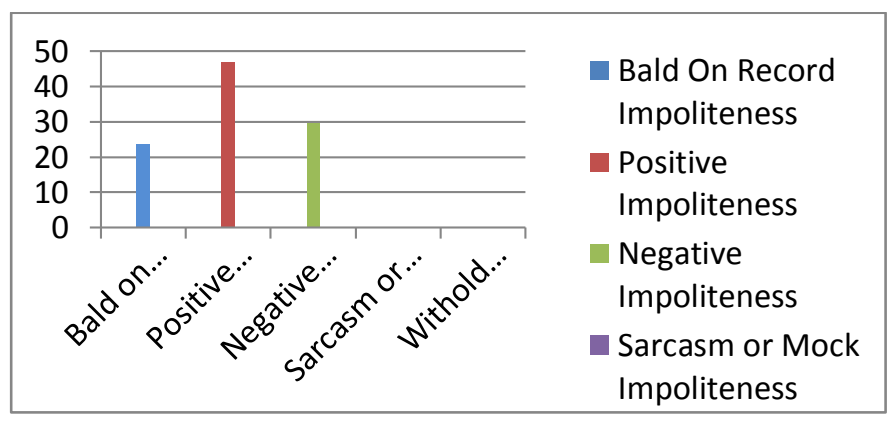

In Figure 4.1 it is shown that the most frequently impoliteness strategies used was positive impoliteness, followed by negative impoliteness and then bald on record. The researcher did not find sarcasm or mock impoliteness and withhold impoliteness.

Data 1:

BTP : "Pasangan ini ngomong kami hanya membangun fisik, jembatan segala macam. Bukan. Karena kami ingin memperbaiki orang.”

It can be seen from the data above, BTP wants to show his rejection or ignorance of what candidate 1 says that he builds not only Jakarta but also the peoplebecause in the previous statement candidate 1 only tells about the physical development of Jakarta. This strategy belongs to the positive impoliteness. 
Data 2:

$A R B$ :"Ijinkan saya mengingatkan bahwa 5 tahun yang lalu pernah ada janji. Dan janji itu mengatakan akan dibangun kampung deret di pinggir-pinggir sungai. Di mana janji itu?Di mana kontrak politik itu? Kontrak politik ditandatangani"

The utterance of the ARB above can be categorized as negative impoliteness. It can be known from the question of ARB asking or billing promises previously submitted by BTP but not yet realized until specified time.

Data 3:

ARB : "Karena itu Pak Basuki, jangan hanya kerja-kerja-kerja. Harus punya gagasan, harus punya kata-kata. Karena dua itu memberikan narasi. Dan Bung Karno. Bung Karno mengatakan, banyak bicara banyak bekerja. Bukan hanya banyak bekerja banyak bicara."

From the data above, it can be seen that ARB wants to reply the question from the presenter and affirms to BTP that in building Jakarta it is necessary to use ideas not only working. Therefore, the utterance is concluded as bald on record which shows the impoliteness because ARB directly addressed the word "Pak Basuki" to BTP.

Related to the realizations of impoliteness strategies, there are many ways used in each strategy. Positive impoliteness was used in 7 realizations. The realizations were ignore and snub the other, dissasociate from other, be disinterested, use obsecure or secretive language, seek disagreement, make other feel uncomfortable, and call other names. The most dominant realization used was make other feel uncomfortable.

Data 4:

BTP :"Dan apalagi yang akan kami katakan, visi kami ini terukur dengan angka, apa angka itu, itu adalah indeks pembangunan manusia makanya jangan heran Jakarta nomor satu. Malahan kita terima empat piagam dari Bapenas. " 
The BTP in conveying his statements tries to demonstrate the achievements that he can carry out in his programs as a Jakarta government or boast of an improved human development index (HDI) and in that way he tries to make other candidates feel uncomfortable with his achievements.

Data 5:

BTP : "Di dalam visi misi program kami yang dimaksud dari pasangan calon $3 \underline{\text { itu }}$ bukan strategi, karena kalau strategi kami itu adalah transparansi, non tunai. Nah ini kami namakan kebijakan. Kebijakan kami, apapun yang dipikirkan dirancang, dianggarkan, harus membuat penuh otak perut dan dompet warga DKI."

The third candidate says that the vision and mission of the BTP is called a strategy, but the BTP ignores it and says it is not a strategy but a policy in their program. The BTP rejects the assumption of strategy and removes the word.

Data 6:

BTP : "Nah makanya kalau kita hanya mengatakan membangun, membangun manusia, tidak ada bangun benda matinya itu namanya apa tau gak? Itu namanya teori. Ngajar jadi dosen, di kampus, itu ya teori. Cuma ngomong saya mau bangun ini, mau bangun itu, bangun ini tapi ga ada action-nya. Kalau kami? Kami tahu tujuannya.Visinya jelas, terukur. Ya harus membangun, harus ada. Harus ada fisik supaya sumber manusia ini tercapai. Nah saya kira pasangan nomor 3 gayanya memang dosen kali ya."

When the speaker tries to distance himself from the conversation of others and feels not part of the other speaker's topic. The speaker also want to show that he is different from others or the intended of the speakers.In his statement BTP wants to show that he is not the same as ARB who has a style like a lecturer and who he thinks can only provide theory 
without giving action. He does not want to look the same as ARB by saying "Kalau kami? Kami tahu tujuannya. Visinya jelas, terukur.”

Data 7:

ARB : "Saya rasa sederhana. Pertanyaannya bagaimana membangun manusia? Jawabannya ga nyambung sama sekali. Karenaitu, karena itu”

When the speaker feels uninterested or displeased with the discussion of his interlocutor, he shows his disrespectful attitude.This statement comes out after the BTP responds to his work program that is considered only work without giving respect for the word. Then ARB directly interrupts that BTP words are not connected at all and are not interested in saying "Jawabannya ga nyambung sama sekali."

Negative impoliteness was used in 3 realizations. They were condescend scorn or ridicule, invade the other's space, and explicitly associate other with negative aspect. The most dominant realization was invade the other's space.

Data 8:

AHY : "Bapak punya alasan tentunya mengapa menggusur, tetapi bagaimana perasaan bapak sebagai pemimpin sekaligus pengambil kebijakan tersebut melihat warga yang hidupnya semakin sulit begitu semakin sulit? Dan akhirnya kehilangan segalanya."

When the speaker speaks of weaknesses or what can be the object of dropping his opponent, he usually invades or always talks about his opponent's weakness to show that his opponent is not as strong as heis. The eviction system was one of the BTP's work programs while serving as governor of DKI Jakarta. In conveying his statement, AHY attacked the BTP's work program which he regarded as a program that could only hurt the people whose 
lives are difficult, not to improve the life of Jakarta residents. In other words, AHY attacks by scorning the BTP's work program in case of eviction.

Bald on record impoliteness was used in 3 realizations. The realizations were direct, clear, and concise way.

Data 9:

AHY : "Inilah masalahnya. Pemimpin yang selalu curiga dengan rakyatnya sendiri. Pertama tadi pertanyaannya, bagaimana meyakinkan agar masyarakat tidak masuk penjara. Selalu otaknya bagaimana supaya masyarakat tidak masuk penjara, bagaimana pertanyaanya kalau mereka berhasil? Tidak pernah ditanyakan."

Direct happens the speaker attempts to utter or respond to a statement directly from the listener or by pronouncing the name or position of the person being discussed.In AHY's statement, he pointed clearly to the BTP who at that time is still the governor of DKI Jakarta and said that the BTP is always suspicious of his own people.

Language impoliteness which were uttered by the candidates governor should not be occured for the reason that debate was the setting where the politeness should be worked because it was a formal place. It means that the governor candidates are expected to speak politely to each other.On the other hand, the analysis showed that there were some reasons why the candidates governor speak impolitely in debate. They are to vent negative feelings, to mock others, to show disagreement, to show power, and to clarify something.

Data 10:

BTP : "Saya udah jelaskan kadang-kadang kami ini suka ketawa juga, seolah kami ini nggak suka orang miskin, benci orang miskin. Tadi pasangan nomor 1 mengatakan mau kasih 600 ribu per bulan, itu terlalu kecil Bapak. 
The data above shows that in the previous statement the other candidates said that BTP program was always make the poor people became miserable. Then BTP responds by saying that the other candidates also provide a budget that is too small for the citizen of Jakarta. This is one example of to vent negative feelings.

They applied this way to entertain the others and it was an effective strategy in utilizing the impoliteness in election debate. In the following data would provide the reason why candidate governor used the impolite language in election debate:

Data 11:

BTP : "Cuma ngomong saya mau bangun ini, mau bangun itu, bangun ini tapi ga ada action-nya. Kalau kami? Kami tahu tujuannya.Visinya jelas, terukur. Ya harus membangun, harus ada. Harus ada fisik supaya sumber manusia ini tercapai. Nah saya kira pasangan nomor 3 gayanya memang dosen kali ya."

The data above indicates that the BTP used impoliteness strategy in reason to mock other candidates by saying he just using theory for some explanation, without any practice in this case a lecturer.

Data 12:

BTP :"Di dalam visi misi program kami yang dimaksud dari pasangan calon $3 \underline{i t u}$ bukan strategi, karena kalau strategi kami itu adalah transparansi, nontunai. Nah ini kami namakan kebijakan. Kebijakan kami, apapun yang dipikirkan dirancang, dianggarkan, harus membuat penuh otak perut dan dompet warga DKI.

Nah di sinilah perbedaannya. Pasangan ini (nomor 3) ngomong kami hanya membangun fisik, jembatan segalam macam. Bukan. Karena kami ingin memperbaiki orang." 
In election debate, the governor candidates did not always have the same idea with others.The previous candidate governor used the word "strategy" in response to the BTP work program, but the BTP did not agree with the use of that word because they regard it as a policy rather than a strategy.

Data 13:

\author{
ARB :"Bila tadi kita dengar, pasangan calon pertama memberikan ikannya. \\ Pasangan kedua memberikan kailnya. Ikan dan kail baik diberikan.Tapi jika \\ kolamnya masih ada, bagian kami menyiapkan, memastikan kolamnya masih \\ tersedia."
}

In some occasions, the power between governor candidates seemclearlydifferent. This power struggle would occur to show the dominance of each speaker in their interaction.ARB used the parable of hooks, fish, and ponds in conveying opinions. If itcan be seen from those, what is given by candidate number 1 and 2 will not be useful if he does not provide the pool. So he shows his strength or superiority over other candidates.

Data 14:

ARB :"Di sana tak ada moral, di sana tak ada karakter, di sana tak ada nilai. Justru yang mau kita bangun adalah iman, taqwa, akhlak, karena yang dibutuhkan bagi masyarakat Indonesia adalah pendidikan yang menumbuhkan karakter moral dan karakter kinerja. Karakter moral artinya jujur, berkarakter: ikhlas, tuntas, beriman, tetapi karakter kinerja, kerja keras, kerja tuntas. Pendidikan bukan sekedar penyiapan ke pekerjaan."

Every governor candidate has the same right to speak up especially in clarifying something to be clear. ARB previous position as the Minister of Education made him giving 
an explanation that the purpose of his program is not only to build and improve the students' knowledge, but also their moral, faith and character.

The most dominant reason to use the impoliteness strategies was to show power. Moreover, it is also revealed that both two different types of impoliteness strategies and two different realizations were used at the same moment.

\section{ACKNOWLEDGMENT}

The writer would like to express respectfulness to Prof. Dr. Sri Minda Murni, M.S and Prof. Dr. BusminGurning, M.Pd as her thesis advisors for guiding her to accomplish her thesis and for giving useful knowledge and suggestions.

\section{REFERENCES}

[1] Culpeper, J. 2011. The Palgrave Handbook of Linguistic (Im) Politeness. Uppsala University.Routledge

[2] Beard, A. 2000 The Language of Politics. Routledge

[3] Ayeomoni, O.Moses. \&Akinkuolere,O.S. 2012.A Pragmatic Analysis of Victory and Inaugural Speeches of President Umaru Musa Yar"Adua.Journal of Theory and Practice in Language Studies, Vol.2, No.3,pp.461-468

[4] Lakoff, R. 1989. The limits of politeness: therapeutic and courtroom discourse. Mulitilingua 8. 101-129. Berlin: Mouton de Gruyter.

[5] Leech, G. 1983. Principles of pragmatics. London: Longman.

[6] Bogdan, R.C., \&Biklen, S.K. 1982. Qualitative Research for Education: An Introduction to Theory and Methods. Needham Heights: Allyn and Bacon. 